\title{
ESSAY
}

\section{Queer. Caribbean. Miami. Boy: A Personal Geography}

\author{
Kevin Quashie \\ Brown University, US \\ kevin_quashie@brown.edu
}

Kevin Quashie reflects on growing up Black in Miami and how it has shaped his intellectual pursuits.

Keywords: St Kittsian; small-island migration; Opa-Locka; language; desire

When I was almost fourteen, in the summer before tenth grade, I wrote a really bad poem about language. Actually, the poem described my struggle to claim a mother tongue. That phrase, "mother tongue," had somehow worked its way into my imagination, perhaps borrowed from overheard conversations between my parents and their Caribbean friends. It was not an idiom I would have used in everyday speech, though I'm sure I must have been seduced by its grown-up sassiness.

The year was 1985 and my family had just moved from St. Croix to Florida. Before St. Croix, we lived briefly in New York (Brooklyn) and, before then, St. Kitts where I was born. Most of these moves followed changing work fortunes for my father, then a petroleum inspector; my mother, who worked as a nurse and domestic and optometric assistant-sometimes overlappingly-never did not work. So Miami it was, specifically an Opa-Locka apartment complex that housed other small-island immigrants (e.g. from Antigua, Dominica, St. Lucia) and black Americans. Though we had lived in apartments before, nearly everything felt foreign in this cavalcade of units around a dirty swimming pool unused for years. Not quite squalor but no one who owned the place seemed to want to care for it. Then as now, my literary inclinations absorb and animate the specificity of everything. As such, I remember this summer-living through the prism of Gwendolyn Brooks's In the Mecca, that vibrant catalog of black Chicagoans living life. In Brooksian light, my Opa-Locka is a place of people heading off to work, having arguments, complaining about the cost and taste of bread at the Circle $\mathrm{K}$ across the street. There is, too, crime and social hardness, and Miami's July heat. Sometimes, there's music from a window or a car.

This memory could be of a black anywhere but it belongs to the diasporic circulations of Miami in the 1980s where a black boy dreams in language, loves Tina Turner, and makes lunch every summer weekday for Ms. Caroline, a family friend two doors down who was recovering from surgery. I knew Ms. Caroline from St. Kitts, though it had been at least seven years since I had seen her. Still, she remembered me with fondness and I was diligent in delivering daily a covered plate with a proper starch, a meat, and a vegetable. I wielded care as currency and soared on the faith of Ms. Caroline's temporary adulation.

I was a fat femme boy who had two older sisters. I knew the gender aberration of being assigned this task of hospitality. I knew it was given to me partly as an act of diminishment, in the way that the domestic is imagined to feminize and demean. But the almost-fourteen me, of Virgo lineage, relished the chance to be adored for his creativity and diligence.

My mother-tongue poem features a transparent speaker (me) trying to figure out which English to speak. It is not a good poem but-because of-its mediocrity, it manages to compound what I understood as the treacheries of expression. The speaker (me) worries: about being misapprehended if he speaks a thick

\footnotetext{
${ }^{1}$ Brooks's In the Mecca was published in 1968 and chronicles the lives of black people living in an apartment complex during the search for a missing young girl. Key to the work's poetics is the position of the speaker, a keen observer whom Kristen Ortega Bartholomew reads as a "flâneuse."
} 
Caribbean demotic: about white high school teachers who might find the accent charming or illegible (both things happened, especially in a spelling bee when I pronounced the letter as "zed"): about being alienated further from the black American boyness he so craves, the slick lyric slang that eludes him (though I didn't admit that being attracted to these boys deepened the alienation): about sounding more like Caribbean women than like men (my pitch, my propensity for teeth-sucking): about his affection for Peter Jennings, the longtime white Canadian anchor of ABC World News, whose lilt seemed like a voice of clear human authority: about the treason it would be to speak like Jennings, particularly how it would rile his father (all my speaking, in any register, seemed appalling to my father).

What is the relationship between the voice of one's interior and the voice in which one speaks to the world? This is the poem's query though I am too young to phrase it this way. At almost fourteen, the chasm between my (exterior) silence and my (interior) tumult seems unbearable. ${ }^{2}$ And since my grandmother, my sole confidante, died six years earlier, I do my sussing-through in this messy poem which concludes, most amazingly, with a decision to lose weight. This conclusion is one of those non-sequitur shifts that flourishes in naivve verse. And still, abrupt as the volta is, it signifies my youthful appreciation of voice as a metaphor for subjectivity; it lays bare how much racial, ethnic, and national filiation rampages my adolescent consciousness ... and how much this rampaging is indexed to an understanding of my fleshy feminine lispy dark-skinned boy body.

On the cusp of fourteen, I am a fat round jelly-ish boy with a soft high-pitched voice. I am of ordinary height if not outright short, am quick to smile so as to try to radiate warmth and curry favor. I am, perpetually, of quivering.

I live in terrifyingly disciplined apartment with three sisters, my mother, and my father-my father who is a tall husky handsome deep-voiced man, compelling and commanding, he who stammers when triggered to anger. Other than the stammering, I have no evidence of any wavering in his tenor or accent or clarity.

I am an introverted black boy, a migratory subject in a city of migratory subjects. I am almost fourteen and am grappling with what kind of male being I am and can become. ${ }^{3}$

This becoming happens in the inevitable shadow of my father but more precisely in the distinct sweet company of three men.

\section{One: Mr. James}

Those long slender fingers, lean flickering things that move gracefully ... not with too much flourish, since he is, after all, an elementary math teacher in black Miami. Not with too much flair but if you are watching carefully, you can see the arc of something there in every gesture.

I am watching Mr. James: It is October 1986 and I am tutoring his students after school, mostly helping with homework and showing them math tricks. I'm a junior at a high school six miles away, but his elementary classroom is down the street from the Carol City house my parents just bought. I can't remember now how we agree to work together but I know it wouldn't have been a complicated decision since I am barely in two clubs at school (they meet randomly, often at lunchtime). When other students are hanging out after school-the queer boys and their cheerleader friends, the football players, the drama and goth crews-I am usually on two buses (the 83 then the 27) heading home.

I am a well-behaved studious Caribbean boy child who wears thick glasses, who is tolerable or invisible because he never is any trouble. I am quietly swishy, not the full-time sissy that Marlon Ross describes or the unabashed aunty-man my father warns me of; just fat and femme, my body betraying its lightness akin to the dancerly work of Mr. James's fingers.

That classroom is a refuge for me, not only because of Mr. James's warmth (he has a hearty laugh) and his spirit of collaboration (he is deliberate in planning the day's doings with me) but because I get to spend gentle giggly time with people young enough to crave attention from a soft black boy. Some days Mr. James leaves us alone together and after we finish our math things, we break out into song, a parade of soul hits by Stephanie Mills, Meli'sa Morgan, Alexander O'Neal and Cherrelle, Anita Baker. These moments are salvation for my not-quite-sissy boy self who is surrounded by rap sounds that he can't embrace. (Not yetthat will come later, through Katrina Laverne Taylor aka the Diamond Princess Trina.) Then, as now, I love

\footnotetext{
${ }^{2}$ I am leaning here on the argument about quiet and interiority as distinct from silence as an absence or withholding or an imposition; see Quashie, The Sovereignty of Quiet.

3 I am borrowing here from the title of Carole Boyce Davies's Black Women, Writing and Identity: Migrations of the Subject. Further, my thinking about voice, gender, and Caribbean subjectivity is informed by Marlene NourbeSe Philip's She Tries Her Tongue, Her Silence Softly Breaks, especially the essay "The Absence of Writing or How I Almost Became a Spy."
} 
mid-eighties R\&B: Ready for the World, Janet Jackson, Whitney Houston and Teddy Pendergrass like velvet on "Hold Me." Shirley Murdock.

On those days, song fills the world of that room like weather. We sing and sing, and then hurry up to get to the next. Even when Mr. James returns, he isn't alarmed by or dismissive of our performing. He knows we've done our work but more than this, he knows-better than me-that although the logics of denominators and decimals matter, what is of truer value is the being together, me this black teenaged boy, they these black children, in company, not across the street at the convenience store buying sausage sandwiches (though we did that too), not wandering where something difficult might happen.

We are together, inside, and as the sun beams relentlessly through the windows, we sing. One day, I light into a Billy Ocean song so earnestly, so full-in-my-gut, that one of the students, a girl, comes to me and says "You sing beautifully." Her eyes hold mine as if she knows something. I look then look away.

That was over thirty years ago but I still remember the nudge of her declaration. My singing was and remains ordinary at best, but somehow that young girl notices something in the way I inhabit those lyrics about sad songs and love's redemption, that idea of heartbreak as wonder. She, this young black girl-she would have been in fourth grade, so she could not have been more than nine years old-she is tender to me in a moment when I am using my voice.

It was-is-a genuine simple act of being seen, a remarkable caress in a small casual thing.

Small casual things: "Mr. James" is not his real name, though I want so badly to call his name in holy honor, he a lithe man who was firm but kind. At the end of each week, we would meet to review and plan for the next; at the close of those meetings, he would always wish me well, something plain like "I hope you have a very good weekend, young man," except that it was amplified by a sentiment I can't quite place. (Maybe it's his eyes holding mine or his hand on my shoulder; maybe it's the treble of his voice.) I sensed that he sensed that I was of fear. Sometimes, without saying anything more, he would take my hand and slip \$20 into my palm. This happened no more than three times in the two years I worked with him. And though I hadn't exhibited neediness and we were both of the same working-poor neighborhood, the money was put to good use on weekend trips to the mall with my seven-year-old sister. (She and I had a routine: a jaunt through Toys-R-Us, Bojangles chicken dinner with dirty rice, hot mini chocolate chip cookies from Mrs. Fields.) It was money quickly spent but the gift, really, was the prayer of his fingers passing across mine.

That beautiful black man, light brown of skin, Jamaican by birth, slight in his accent: This time with this man was an erotic education for me, erotic in the Lordean sense because it was about being of deep severe feeling. ${ }^{4}$

Sometime in that arc of days with Mr. James I lost over one hundred pounds.

I know enough to distrust collating one thing and another; still, I believe that it was somewhere in his company that I learned how to be of regardlessness, as Alice Walker might term it: Regardless the things of the world, to be of one's self. ${ }^{5}$ There, in a fourth-grade elementary classroom, in communion with black children younger than me, in the watchful care and tenderness of an adult black man whose slender dancerly fingers were like the full moon, there in that world, Billy Ocean's modest lyrics became superlative: "There'll be sad songs to make you cry, love songs often do,/They can touch the heart of someone new saying I love you, I love you."

\section{Two: Carlton}

Actually, the words weren't quite "I love you" but something nastier, something thrilling and delicious. And they were whispered in a walk-in cooler at McDonald's where I had started a job days before I turn sixteen, weeks before my senior year.

It is July 1987 and I am roused in my newly smaller body, almost always throbbing with music. When no one is home, I move the couch up against the wall and dance for hours to songs by Exposé, Whitney, Jody

\footnotetext{
${ }^{4}$ I am referring here to Audre Lorde's argument in "Uses of the Erotic: The Erotic as Power" as well as to the Lyndon K. Gill's engagement of Lorde's essay in "In the Realm of Our Lorde: Eros and the Poet Philosopher." Further, my consideration of the aesthetics of the erotic is inspired by Donette Francis's thinking about romance/antiromance in Fictions of Feminine Citizenship and Omise'eke Natasha Tinsley's study of the female erotic in Thiefing Sugar.

${ }^{5}$ I am referring to the third movement in Walker's definition of womanism, which closes with the word "regardless"; see In Search of Our Mothers' Gardens: Poetry and Prose, Harcourt, Brace, Jovanovich, 1983, pp. xi-xii. In my current book project on black aliveness, I read this invocation of "regardless" as an ontological and ethical formation.

${ }^{6}$ My thinking about subjectivity through black music is indebted to the enduring work of Mark Anthony Neal (especially Songs in the Key of Black Life and Soul Babies), Nelson George (The Death of Rhythm and Blues and Hip Hop America), and Ferentz Lafargue (Songs in the Key of My Life).
} 
Watley, Lisa Lisa and Cult Jam, Madonna, the Cover Girls, sounds so different from the soca/calypso, reggae, and gospel that my parents favor. I am keen to instances of my emergence-like this job, full of burdensome blessings and which requires a forty-minute walk each way. Too timid to look for a shortcut (between houses, across a wooded field), I take the most straightforward path along US-1's busy four lanes of traffic. As cars buzz along, I hum songs out loud, twitching in the tight black slacks and sweating in the maroon polo shirt that I wear as an ironic mark of independence. I am unharassed. In my head and on my tongue are the latest remixes by names I am glad to know-Frankie Knuckles, Junior Vasquez, Jellybean Benitez-for even as I am too young for Miami's clubs, my body is a house scene of its own.

I am a boy in full blossom and ready for a whisper.

His name is Carlton and he's a co-worker, skinny, dark brown, probably twenty-five years old. His voice is deep (me and these deep-voiced men) and his lips glisten as if they have just been licked. This seems impossible but it is also how they are every time. From early on, Carlton smiles at me; sometimes he winks.

I don't know what he knows; I want to know what he knows.

As in most restaurants, food prep at this McDonalds is gendered male-there are a few older women who cook but the grill is mostly a space of male competence. And since nearly every worker at the store is black (American or Anglo/Spanish Caribbean), this gendering becomes a faultline of regard. Nobody messes with the women on the grill, for example, not even the white managers, which is to say that all the grill workers are untouchable. That part of the store is rife with authority, its own language, a quick capacity to judge those of us who don't cook. The rare praise for making it through a rush-period always goes to the back of the house.

Carlton works on the grill though sometimes he is pulled to do other tasks. I prefer the encasement of working drive-thru (even though customers regularly take my voice for a girl's) but mostly I am assigned one of the front registers. With the black girls.

These girls fascinate me: they radiate fabulousness and are decked in painted nails and styled hair (with baby hair!), chains and pendants and rings glossing up their uniform. Their lips are lipsticked excessively and exceptionally. And confidence-they reek of it even if it is a bravura invented on the spot and mobilized as a shield against vulnerability. When work is slow, they corral with the two other queer boys who are never scheduled the same shifts as me but who come early or stay late to help hold court. These girls toggle between being salty and being aloof to customers, and they flirt with and are teased by the grill boys. ${ }^{7}$

I am seduced by their togetherness, terrified by my exclusion from them. In my quiet and solitariness, I work dutifully even though I mostly feel gullible as I scrub baseboards or stock up at the end of the night.

I believe that no one sees me though Carlton is watching.

There is an iconic scene in Toni Morrison's Sula: Nel and Sula, both eleven-year-old black girls, are walking by Edna Finch's ice cream parlor. Outside the store is a flock of young black men, including Ajax who is nearly twenty and as the girls pass, he utters a phrase that has no clear dictionary meaning but that is nonetheless exact: Pigmeat.

Morrison sets the scene exquisitely, highlighting the girls' determined craving on a day when "it was too cool for ice cream" (49). This notation marks a context of inappropriateness, a thing somewhat out of place or a bit wanton and still too compelling to avoid. I say "inappropriate" but Sula is an ars erotica and the idea of appropriate is hard to scale there. The truth is, all of living is risk, sometimes more so because of one's age, gender, race, but all of living is deep risk. ${ }^{8}$

Ajax said pigmeat, that nasty-ass phrase.

I can't remember exactly what Carlton says in the cooler so I always think of that Sula moment when I recall his doing. There had been many moments of encounter between us, times when he'd come over-the only grill cook to talk to me-and ask simple questions: How I was doing, how was school, even interest in my college applications. (Save for him, I dreaded walking past the grill area and its intensified maleness.) Beyond these brief exchanges, he was playful too, like a hand resting on my shoulder or a "hey sweetness" as a greeting, a playfulness which was never in full view of our peers but never really out of sight either-as if secrecy didn't matter to him.

Everything about his outreach thrills me; it feels right to be tendered in the swagger of this fine black man. Carlton has such an astute awareness of me-he seems to know that I am singular and isolated in that restaurant. He finds me in places where we can be alone in the midst of others. Sometimes he taps me on

\footnotetext{
${ }^{7}$ It seems important to note that all of us working the front registers are teenagers. I want to acknowledge, too, that I am conflating varied manners of being here in this snapshot.

${ }^{8}$ For an extended consideration of the novel as an ars erotica, see Quashie, "To Be (a) One: Notes on Coupling and Black Female Audacity."
} 
the ass, slyly and in camaraderie. His "hey sweetness" and these other overtures are delicious. Devastating too, because I want to be taken right then, devastating because I feel bereft when he walks away. He leaves me wholly and wreckfully undone though I never ever feel unsafe: not when we meet near the bathroom door, not when we are two of four people working late (me stocking condiments, he scrubbing the grill). Never unsafe: just seen, coveted, tracked even, of yearning. Maybe it should be called witnessing, something relational, since I slyly take my bathroom breaks just as his mopping nears that corner of the store. ${ }^{9}$

He wouldn't have known I was sixteen. And we are, in this moment, both living in urban Miami in 1987 where regard for gay young black men is low and the ravages of AIDS are high. We, this man and I, are living surrounded by a discourse that disparages homosexuals, Haitians, Africans generally, drug users, sex workers. It is less than seven years past the Overtown/Liberty City riots. In our churches and homes and schools-never mind elsewhere-there is not much concern for black boys like us. We live encircled by the dominance of fear, silence, and hate.

In the freezer that one day, he said the most explicit thing, something about wanting my ass but the language was more poetic than that, more determined, phrasing so new to me that l'd never heard it before and can't remember its precision now.

I melt still in recalling this thing I can't recall properly.

It never happened. I don't know why. Maybe it was because I lived at home, and neither of us had a car where we might have fucked in a parking lot. Maybe he assumed we had more time. Maybe he knew it would not happen, that it didn't need to happen. Maybe these conjectures ascribe to him all the agency when, in truth, we were cohered together. It never happened and oh God I miss its happening.

I left that job one July day in 1988, just around the time that the Jungle Brothers released "I'll House You," a song whose chorus rings like an anthem: "Girl, I'll house you/You in my hut now." These words capture the righteous invitation of Carlton's walk-in freezer poetry such that he might have well said "I'll house you."

I never saw Carlton again. Months later I thought I heard a rumor that he had died. Hearing this-thinking I'd heard it-made me revisit the memory of his lean body though I was then and am now reluctant to read something terrible on his frame. Indeed, the same dynamic happened when I asked around about Mr. James: It seemed that he did die but the unconfirmed news was cloaked in homophobic whisper and I can't bear to surrender his slim dancerly fingers to that small imaginary. It is not that I am trying to stymie the truth but simply that I want to forestall another moment of black queer unseeing. I see them both as they were and are; I see us. ${ }^{10}$

I missed Carlton and miss him still, this man who, when everything about working-poor urban Miami was being ignored or killed off or neglected, when a gay boy like me might have been blighted into certain destruction, he said "I'll house you."

\section{Three: Justin}

I feel like pure fire in the wake of Martha Wash's rapturous vocals off of "Gonna Make You Sweat (Everybody Dance Now)." It's a little bit of peril to be this close to him in public but it is 1989 and our dancing registers as battle or kinship-as if in audition for a Bobby Brown video-more than something queer. We are at Thursdays-by-the-Bay, a weekly party at FIU's Bay Vista Campus. I'm a sophomore racing through credits and majors but most of all, I'm dancing with Justin, my first boyfriend, exquisite long-legged mover. Any night we're together, even if just in my dorm or his apartment, we can be found bouncing through the whole repertoire: the running man, the wop, the cabbage patch, even little snatches of vogueing. On the FIU dance floor, there is no grinding together but our doing is competitively full of tension that will pay off mightily later when we are alone.

"Sweat," Martha says, "swaaa-aaiitt," and I am determined to follow instruction.

I meet Justin five months earlier through a personal ad in The Miami Advocate. Since the phone message service costs money, we write letters to each other instead. In the second letter Justin mentions that he is dating a man and a woman but I am already taken with the way he narrates everyday happenings. Before I ever hear his voice, I decipher his warm looseness on the page. I love, too, that he always writes about music-songs he's listening to, his latest trip to the record store, an upcoming concert. So much of this

\footnotetext{
${ }^{9}$ In addition to Sula's Ajax moment, I think of this happening akin to the story Essex Hemphill tells in "Ceremonies" about the young speaker's sexual encounters with an older white man, the complicated scenes of black erotic becoming. On witnessing, see James Baldwin's articulation in the preface of Evidence of Thing Not Seen, Joshua Miller's "The Discovery of What it Means to be a Witness: James Baldwin's Dialectics of Distance" and Ed Pavlić's "Open the Unusual Door: Visions from the Dark Window in Yusef Komunyakaa's Early Poems."

${ }^{10}$ I can't help but note that I am sensitive to reading any narrative on a body especially as one who grew up fat black queer and femme.
} 
seems idyllic but then again Justin is the kind of man my parents would want me to marry, if they could withstand imagining me queerly: He's a senior at the University of Miami, handsome and outgoing, charming in his smoothed-skin biraciality (his mother is Haitian, father's French), a budding DJ who is also a science major. My father would love the islandness in his voice (it rests on the edges of his vowels, especially in the way he soft-breathes my name or trips over words when excited) and would love, too, what he'd read as strength in Justin's extroversion. My mother would swoon at how pretty and kind and funny he is. Justin is liked by everyone; indeed, he is the pride of his fraternity, though given that we party at my school, I am not sure that his brothers know of him.

Everything of him I remember through music. Like our first date, an all-day Saturday affair which started at a Peaches Records where he knew the staff and could get access to secret stashes of remixes. To this point, we've only spoken on the telephone (twice). I am wearing red shorts that hug my thighs and Justin ends up carrying my wallet in his left jeans back pocket. Days later, he is the first person to make a mixtape for me, and though I can't recall its sequence of songs, I remember well the one I made for him, also a first. Mine comes with a letter, a declaration of love that really is an oblique ultimatum (pick me or him or her; pick me). Ah, that tape includes Luther Vandross's "For You to Love," something from Quincy Jones's Back on the Block (Tevin Campbell's “Tomorrow"?), Stacy Lattisaw's "Don't Throw It All Away," Anita Baker's "Angel," Richard Marx's "Right Here Waiting" (an outlier for sure but it was also the year's biggest pop single). There must have been other songs too though it is "For You to Love" which I use as inspiration in the letter. "It's the middle of the night, and I can't sleep at all, I'm so uptight," Luther croons on a song that balances pleading, savvy (it opens with a finger snap!), and eagerness. Both letter and song speak of my capacity and my preparedness: "It's the middle of the night" I say, and then "I came here, for you to love-in the pouring rain, for you to love." This secures him as mine and mine alone.

You should know that everything of me I remember through the music. I know that this mapping is unreliable, even convenient; I know, for example, that it was Justin who introduced me to the Jungle Brothers, even though their song seems so anchored to what I heard Carlton say. This telling is as memoir is: idiosyncratic and affective and piecemeal. ${ }^{11}$ It is a telling in music since it is through music, and through music with Justin, that I become audacious. I begin to act subjunctively, as if the aliveness in my head or heart-as if the voice in my poems and other writings-could be also the habitat of my doings in the world.

I act as if I am as I am: a young black Caribbean man of queer yearning.

It is all of music. Like: The times we went to Sugars, the gay black club just down Biscayne Blvd from my dorm. If you could go there now, amidst the most beautiful-est black boys in the world, you would see me and him cased by the dark and wrapped in the sweet of Soul II Soul's "Back to Life," the single best song of the twentieth century. ("However do you want me, however do you need me.") You'd see how he looks at me then, how I am not afraid to be seen and how, for a moment, I stop being watcherful. I am just a dervish whirling with my guy, too enmeshed for doubt; the only question I have is carried on the lip of a song. ("How, however do you want me.")

Like: His singing dramatically, sillily, along to Deniece Williams's "Silly" early one Sunday morning as we lay in bed, and then, when "You and I" came on, he sleepily says "God bless Stevie Wonder."

Like: The last four hours of our all-day first date, at his apartment, listening to house mixes I had never heard before while exchanging stories of sexual trauma; and then switching to John Coltrane's A Love Supreme; and then the music to which we got naked, a mixtape of R\&B jams. It is my very first time being naked with a man by choice and all I remember is Freddie Jackson's voice and my body in ecstasy as Justin teaches me that even toes have erotic pulse.

Justin, who looks at me for the very first time in those red shorts and says "Damn, boy," laughing his big hearty comforting laugh. The curse might have confused a younger me, but just then I am ready to bear the whole of his expressive claim.

"Damn, boy."

With him, I am abandon, wrapped fully as one can be in music. With him, it was as if, in the language of one of his favored songs, he said to me "Come bring me your softness"-as if he said this over and over, as if I took each utterance as prayer and was reborn. ${ }^{12}$

Justin: Years later, after we are done and I have moved to Ohio for graduate school, I will write him one final letter, this greatest love of mine, to tell him just that-that he is my greatest love. I will end the letter appropriately with a line from Glen Campbell via Linda Rondstadt: "If you are still within the sound of voice

\footnotetext{
${ }^{11}$ I am borrowing this description of memory from Kathryn Harrison's review essay "Difficult Truths."

12 The song here is Billy Preston and Syreeta's "With You I'm Born Again."
} 
over some radio/I just want you to know you were always my only choice/And where ever you go then I still love you so/if you're still within the sound of my voice."

A bad poem, the quantitative weight of songs, an unremembered whispered thing, some letters to a dancing man: these uncoordinates of a young life.

Let me tell the story again: When I was almost fourteen, I was a fat femme Caribbean boy in a city that reveres beach bodies, though what held sway in my neighborhood is a certain kind of black-boy swagger. I couldn't behold either. We had just moved to Miami and I was looking toward history large and local for a voice, my voice.

When I am almost fourteen, I will write a bad poem about "my mother tongue," a poem which will become the epigraph of a geography of music, a geography of my encounters with and through maleness. ${ }^{13}$

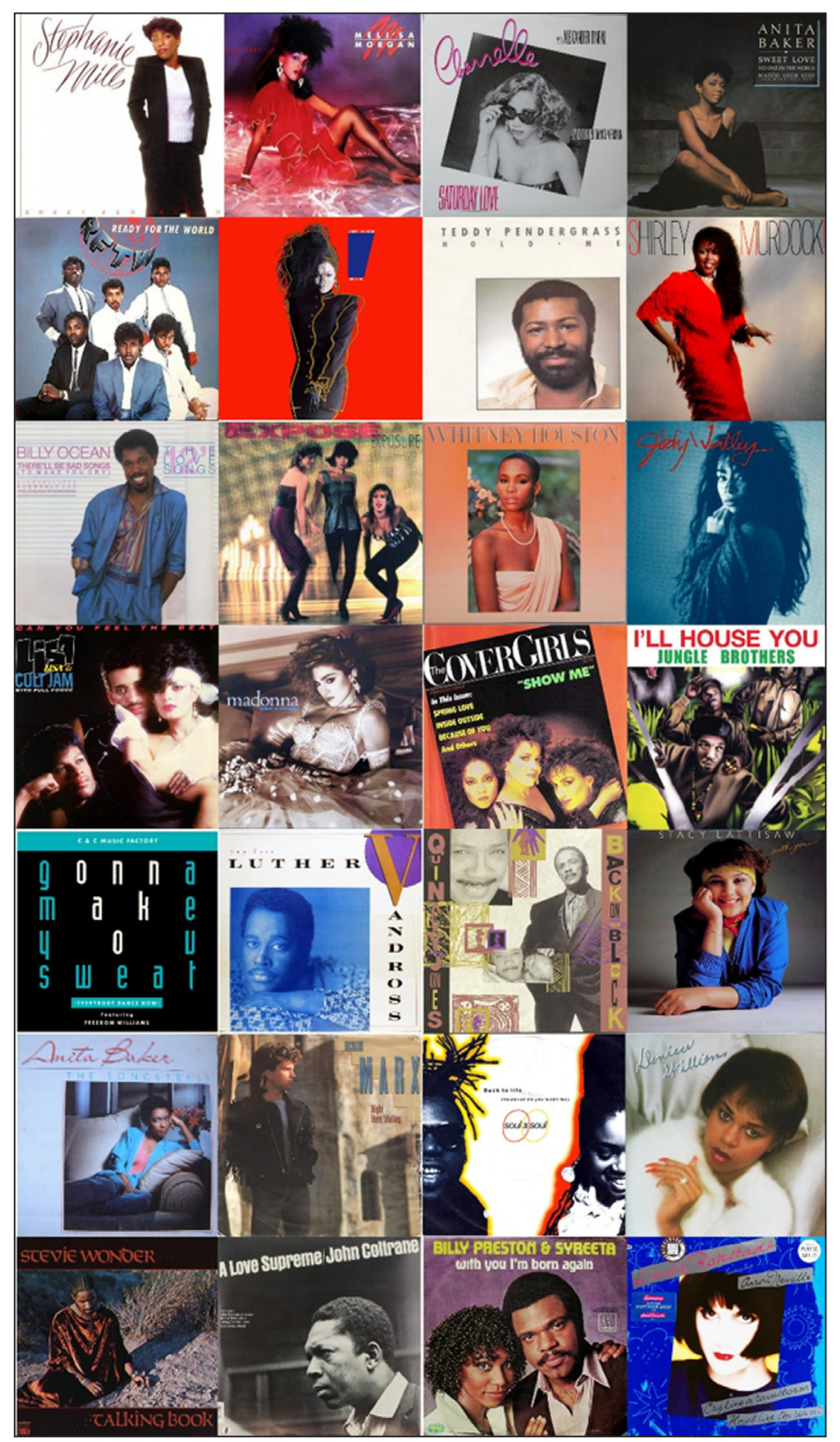

Kevin Quashie, A Personal Discography.

\footnotetext{
${ }^{13}$ These stories bear the mark of all the things that organize my studying and that constitute an intellectual trajectory: music, sex and the queer erotic, black feminist gender thinking, the exploration of a habitat through which one finds and is of aliveness. The phrase "black feminist gender thinking" intends to note black women's particular contributions to theoretical understanding of gendering and racialization as cohered idioms of modernity and coloniality, as is made enduringly plain in Hortense Spillers's "Mama's Baby, Papa's Maybe" and which is revisited beautifully in C. Riley Snorton's Black on Both Sides.
} 


\section{Acknowledgements}

I am in severe debt to Donette Francis for convening the excellent symposium that inspired this writing; to Jafari Allen for a rousing response during the event; to the other speakers: Nathan Connolly, Edda L. Fields-Black, Tera Hunter, Anthony Jack, Jemima Pierre, and Juana Valdes. Gratitude also to the outside reviewer who guided my revisions, including the reminder about the commonsense of Miami's "beach bodies." Finally, I thank John Casey whose care and intelligence is deserving of an essay of its own.

\section{Competing Interests}

The author has no competing interests to declare.

\section{Author Note}

The names Mr. James, Carlton and Justin are pseudonyms, as is the name Ms. Caroline though given how vital each has been to me, I wish I could call their names properly in holy regard.

\section{References}

Baldwin, James. Evidence of Things Not Seen. Henry Holt \& Company, 1985.

Bartholomew, Kristen Ortega. "The Black Flâneuse: Gwendolyn Brooks's 'In the Mecca." Journal of Modern Literature, vol. 30, no. 4, 2007, pp. 139-155. JSTOR, www.jstor.org/stable/30053150. DOI: https://doi. org/10.2979/JML.2007.30.4.139

Brooks, Gwendolyn. In the Mecca: Poems. Harper \& Row, 1968.

Davies, Carole Boyce. Black Women, Writing and Identity: Migrations of the Subject. Routledge, 2002.

Francis, Donette. Fictions of Feminine Citizenship: Sexuality and the Nation in Contemporary Caribbean Literature. Palgrave MacMillian, 2010. DOI: https://doi.org/10.1057/9780230105775

George, Nelson. Hip Hop America. Penguin Books, 2005.

George, Nelson. The Death of Rhythm and Blues. Penguin Books, 2003.

Gill, Lyndon K. "In the Realm of Our Lorde: Eros and the Poet Philosopher." Feminist Studies, vol. 40, no. 1, 2014, pp. 169-189. JSTOR, www.jstor.org/stable/10.15767/feministstudies.40.1.169

Harrison, Kathryn. "Difficult Truths." New York Times, 11 May 2008, BR12.

Hemphill, Essex. "Ceremonies." Ceremonies: Prose and Poems. Plume, 1992, pp. 95-104.

Lafargue, Ferentz. Songs in the Key of My Life. Three Rivers Press, 2007.

Lorde, Audre. "Uses of the Erotic: The Erotic as Power." Sister Outsider: Essays and Speeches. The Crossing Press, 1984, pp. 53-59.

Miller, Joshua. "The Discovery of What it Means to be a Witness: James Baldwin's Dialectics of Distance." James Baldwin Now, edited by Dwight A. McBride, New York University Press, 1999, pp. 331-359.

Morrison, Toni. Sula. Vintage, 2016.

Neal, Mark Anthony. Songs in the Key of Black Life. Routledge, 2003.

Neal, Mark Anthony. Soul Babies. Routledge, 2001.

Pavlić, Ed. "Open the Unusual Door: Visions from the Dark Window in Yusef Komunyakaa's Early Poems." Callaloo, vol. 28, no. 3, 2005, pp. 780-796, Project MUSE. DOI: https://doi.org/10.1353/cal.2005.0137

Philip, Marlene Nourbese. She Tries Her Tongue, Her Silence Softly Breaks. Ragweed Press, 1988. DOI: https:// doi.org/10.25071/1923-9408.23556

Quashie, Kevin. The Sovereignty of Quiet: Beyond Resistance in Black Culture. Rutgers University Press, 2012.

Quashie, Kevin. "To Be (a) One: Notes on Coupling and Black Female Audacity." Differences, vol. 29, no. 2, 2018, pp. 68-95. DOI: https://doi.org/10.1215/10407391-6999774

Ross, Marlon B. "Baldwin's Sissy Heroics." African American Review, vol. 46, no. 4, 2013, pp. 633-651. JSTOR, www.jstor.org/stable/24589859. DOI: https://doi.org/10.1353/afa.2013.0108

Spillers, Hortense J. "Mama's Baby, Papa's Maybe: An American Grammar Book." Diacritics, vol. 17, no. 2, 1987, pp. 65-81. DOI: https://doi.org/10.2307/464747

Tinsley, Omise'eke Natasha. Thiefing Sugar: Eroticism Between Women in Caribbean Literature. Duke, 2010. DOI: https://doi.org/10.1215/9780822393061

Walker, Alice. In Search of our Mothers' Gardens: Womanist Prose. New York: Harcourt Inc, 1983, pp. xi-xii. 
How to cite this article: Quashie, K 2020 Queer. Caribbean. Miami. Boy: A Personal Geography. Anthurium, 16(1): 6, 1-9. DOI: https://doi.org/10.33596/anth.367

Published: 31 March 2020

Copyright: ๑ 2020 The Author(s). This is an open-access article distributed under the terms of the Creative Commons Attribution 4.0 International License (CC-BY 4.0), which permits unrestricted use, distribution, and reproduction in any medium, provided the original author and source are credited. See http://creativecommons.org/licenses/by/4.0/. 